Uludag Univ. J. Fac. Vet. Med.

32 (2013), 2: 63-69

\title{
Isolation of First Local Coranavirus from Cattle with Winter Dysentery in Turkey
}

\author{
Gülşah AKGÜL ${ }^{1} \quad$ Zafer MECITOĞLU ${ }^{1} \quad$ Arife ERTÜRK $^{2} \quad$ Serkan ÇATIK $^{1}$ \\ E.Mutlu TEMIZEL ${ }^{1} \quad$ Veli GÜLYAZ ${ }^{4} \quad$ İrem GÜLAÇTI ${ }^{4} \quad$ Sancak ÖZDEMIR $^{5}$ \\ Kaan ONAT ${ }^{6} \quad$ Bayram ŞENLİK $^{3} \quad$ Sezgin ŞENTÜRK $^{1}$
}

Geliş Tarihi: 04.03.2014

Kabul Tarihi: 30.04 .2014

\begin{abstract}
Winter dysentery (WD) is a very contagious disease of cattle characterized by profuse diarrhea. The precise etiology of disease is still not fully elucidated. Aim of the presented study was investigation of the causative agents of disease in a herd affected by WD and to evaluate routine haematological and biochemical parameters of cows with WD. This study was carried out on blood and fecal samples collected from 12 cows showing typical signs of disease during an outbreak of WD in Bursa, Turkey. Samples were analysed for the presence of bovine coronavirus (BCoV), Bovine viral diarrhea (BVD), Eimeria oocysts and Campylobacter spp. using ELISA, RT-PCR, flotation technique and culture. Faecal samples were inoculated in HRT cell cultures for virus isolation. Isolated viruses were identified as coronaviruses from $25 \%$ of the samples by ELISA, PCR and serum neutralisation tests. Campylobacter spp. was isolated from 33.3\% cows with dysentery. BVD and Eimeria oocysts were not detected in any of the samples.

Results of the presented study indicates that BcoV along with Compylobacter spp. may be the primary agent of WD in cows. However negative results for $\mathrm{BCoV}$ and Campylobacter spp of $58 \%$ of feacal samples indicates that etiology of the disease is still not fully elucidated and pathogens other than $\mathrm{BCoV}$ and Campylobacter could also be involved in pathogenesis of the disease
\end{abstract}

Key Words: Campylobacter, cattle, coronavirus, winter dysentery.

\section{Türkiye’de Sığırlarda Kış Dizanterisinde İlk Lokal Coranavirusun İzalasyonu}

Özet: Kış dizanterisi sulu ishal ile karakterize sığırların çok bulaşıcı bir hastalı̆̆ıdır. Hastalığın etiyolojisi hala tam olarak aydınlatılamamıştır. Sunulan çalışmanın amacı kış dizanterisi ile enfekte olan sürüde etiyolojik ajanların, rutin hematolojik ve biyokimyasal parametrelerin araştırılmasıdır. Çalışmada Bursa bölgesinde tipik kış dizanterisi bulguları gösteren 12 sığırdan kan ve dışkı örnekleri toplanmıştır. Örnekler, bovine coronavirus (BCoV), bovine viral diarrhea (BVD), Eimeria ookistleri ve Campylobacter spp. yönünden ELISA, RT-PCR, kültür ve flotasyon tekniği ile analiz edilmiştir. Dışkı örneklerinde, virus izolasyonu için HRT hücre kültürü yapılmıştır. Örneklerin\%25'inden ELISA, PCR ve serum nötralizasyon yöntemi ile coronavirus identifiye edilmiştir. Dizanterili sığırların \%33,3'ünden Campylobacter spp. izole edilmiştir. Hiçbir örnekte BVD ve Eimeria ookistlerine rastlanılmamıştır.

Sunulan çalışmanın sonuçları göstermektedir ki Campylobacter spp ile birlikte BcoV sı̆̆ı̆larda kış dizanterisinin primer etkeni olabilir. Ancak dışkı örneklerinin $\% 58$ 'i $\mathrm{BCoV}$ ve Campylobacter spp yönünden negatiftir ve

\footnotetext{
Department of Internal Medicine, Faculty of Veterinary Medicine, Uludag University, Bursa. gulsahdemir@uludag.edu.tr Etlik Veterinary Control and Research İnstitute Ankara. 
hastalığın etiyolojisi hala tam olarak aydınlatılamadığı için $\mathrm{BCoV}$ ve Campylobacter spp dışında başka pathojenlerde hastalı̆̆ın pathogenezinde rol olabilir.

Anahtar Kelimeler: Campylobacter spp, sığır, coronavirus, Kış Dizanterisi.

\section{Introduction}

Winter dysentery is a highly contagious disease which causes acute onset of profuse watery diarrhea in adult cattle primarily during winter ${ }^{1}$. Clinical features include explosive watery diarrhea, profound drop in milk yield, variable anorexia, depression and mild respiratory signs. Disease has a high morbidity but low mortality rates ${ }^{2,1}$. The precise aetiology of winter dysentery is still unclear. However in recent years, a bovine coronavirus $(\mathrm{BcoV})$ along with Campylobacter jejuni has been implicated as the etiological agent ${ }^{3-8}$. Concurrent risk factors, such as changes in diet, cold temperatures, and presence of other microorganisms increases the risk of clinical disease in adult cattle infected by $\mathrm{BCV}^{1}$.

The aim of this study was to investigate the causative agents of WD. Therefore stool samples of 12 cows of suffering from different degrees of winter dysentery were examined by ELISA, RT-PCR, and flotation technique also routine haematological and biochemical parameters of cows with winter dysentery were evaluated.

\section{Materials and Methods}

This report was conducted on a cattle breeding farm in Bursa, Turkey at the beggining of the April. The herd consisted of 40 dairy cows. Clinically, 12 cows were found to be suffering from different degrees of winter dysentery. These animals were from various breeds (8 Holstein Friesian, 4 Brown Swiss) and ages (2-7 years). Body temperature, heart and respiration rates (PR and $\mathrm{RR}$ ) were determined by clinical examination. 12 healthy cows from same herd, aged between $2-7$ years were selected as a control group for comparison of biochemical and haematological values.

Blood samples were taken by jugular venipuncture from each cow into $10 \mathrm{~mL}$ evacuated tubes with EDTA (Ethylenediaminetetraacetic acid) or without anticoagulant, to evaluate routine haematological and biochemical parameters. Haematological parameters, including total white cell count (WBC) and differential, haematocrit rates (HCT), haemoglobin $(\mathrm{Hg})$, erythrocyte and platelet counts were esti- mated by an automatic analyzer (Cell-Dyne $3500 \circledR$, Abott Inc., USA). Blood samples without anticoagulant were centrifuged at $3000 \mathrm{r}$. p.m. for 20 minutes and sera were separated and evaluated within $2 \mathrm{~h}$ of collection. Serum biochemistry analyses including potassium (K), sodium $(\mathrm{Na})$, calcium $(\mathrm{Ca})$, phosphorus $(\mathrm{P})$, magnesium (Mg), albumin, alkaline phosphatase (ALP), gamma-glutamyltransferase (GGT), aspartate aminotransferase (AST), total biluribin, (TBIL) total protein (TP), creatinine (Cre), blood urea nitrogen (BUN) were measured by an auto analyzer (VETSCAN ${ }^{\circledR}$, Analyzer, Abaxis Inc, USA). Blood samples were serologically evaluated for Bovine Viral Diarrhea (BVD) virus.

Faecal samples collected within sterile container from all affected and control animals for virological, bacteriological and coccidial examination and cooled as soon as possible. Faecal samples were sent to the Veterinary Control and Research Institute (Etlik-Ankara, Pendik-Istanbul / Turkey) for coronavirus and BVD virus isolation. Bacteriogical cultures and flotation examinations of faecal samples were evaluated at the laboratories of microbiology and parasitolgy of the Faculty of Veterinary Medicine in Bursa, Turkey. Faecal samples were analyzed for the presence of Eimeria oocysts by flotation technique with saturated sodium chloride solution (sp. gr. 1.20) as the flotation medium ${ }^{9}$. For the isolation of Campylobacter species, each faecal sample was plated on Butzler-selective medium (Oxoid) which was supplemented with 5\% defibrinated sheep blood. The plates were incubated microaerophilically at $42^{\circ} \mathrm{C}$ in incubation jars, containing a "Gas Pak" (Campy Gen [AGS]Oxoid, microbiology System) for 48 to $96 \mathrm{~h}$. Campylobacter species were identified by colony morphology, Gram staining, growth at $25^{\circ} \mathrm{C}$, susceptibility to nalidixic acid and cephalotin, nitrate reduction, $\mathrm{H} 2 \mathrm{~S}$ in tirple sugar iron (TSI), and the presence of catalase and oxidase ${ }^{10}$.

In addition standart culture methods were used to isolate Salmonella from faecal samples. In enrichment step, approximately $1 \mathrm{~g}$ feces added into $10 \mathrm{ml}$ of Tetrathionate broth (Difco) containing $0.2 \mathrm{ml}$ of iodine solution, and the mixture was incubated at $42^{\circ} \mathrm{C}$ for 18 to 24 hours. After incubation, the sample-broth mix- 
ture was inoculated onto Brilliant Green agar with novobiocin (BGN; Becton Dickinson) and Xylose Lysine Tergitol 4 (XLT-4) selective media, and both plates were incubated at $37^{\circ} \mathrm{C}$ for 18 to 24 hours. At the end of incubation period characteristic colonies were subjected to biochemical tests to confirm Salmonella spp. and the results were interpreted in accordance with the recommendations by Quinn et al. (2000). Fecal samples were also inoculated onto $5 \%$ ovine Blood agar plates (Oxoid), Mac Conkey agar (Oxoid), EMB agar (Oxoid) plates and were incubated at $37^{\circ} \mathrm{C}$ for 24 hours. Suspected colonies were subjected to biochemical tests and other enteric bacteria, such as Enterobacteriaceae were identified ${ }^{10}$. Faecal samples of cows with diarrhea were diluted with $10 \%$ DMEM medium (Dulbecco's minimum essential medium) containing $10 \mu \mathrm{g} / \mathrm{ml}$ pancreatine, 100 $\mathrm{IU} / \mathrm{ml}$ penicillin, $100 \mathrm{mg} / \mathrm{ml}$ streptomycin and 10 $\mu \mathrm{g} / \mathrm{ml}$ partricine. All samples were centrifuged at $3000 \mathrm{rpm}$ for 30 minutes. Obtained supernatants were filtered through $0.22 \mu \mathrm{m}$ cellulose acetate filters and divided in to cryovials and stored at $-80^{\circ} \mathrm{C}^{11-13}$. Coronavirus antigen detection ELISA test kit (Bio-X Coronavirus detectition Elisa Kit) was used according to manufacturers instruction.

Human rectal tumour (HRT-18) cell culture which was grown in Dulbecco's minimal essential medium (D-MEM) combined with $10 \%$ foetal calf serum was used for isolation of corona virus. For this purpose, 4 faecal supernatants of $1 \mathrm{ml}$ were inoculated on monolayer HRT-18 cell cultures. The monolayers were confluent and incubated at $37 \mathrm{C}^{\circ}$ with $\mathrm{CO}_{2}$ for 1 hour and washed three times with D-MEM plus pancreatine $(10 \mu \mathrm{g} / \mathrm{ml})$ afterwards added to same medium plus pancreatine for propagation of virus and incubated 7 days at $37 \mathrm{C}^{\circ}$ with $\mathrm{CO}_{2}$.

HRT-18 cell cultures were prepared in 24 well plates. Isolated virus strains were diluted 10 fold with D-MEM and $200 \mu 1$ of virus suspension was taken from every dilution and placed into 4 wells. After 1 hour incubation period, all inoculated cell culture wells were washed three times with D-MEM containing pancreatine, added to same medium and incubated for 7 days. CPE formation was observed every day during incubation period. The amounts of viruses were calculated according to Sperman-Kaerber method.

For identification of isolated virus, serum neutralization tests were carried out in 24 well plates containing monolayer HRT-18 cell cul- tures. Isolated and titrated $200 \mu 1$ virus samples were dilueted as $100 \mathrm{TCID}_{50} / 0.1 \mathrm{ml}$ and mixed with $200 \mu 1$ coronavirus hyperimmune serum obtained from rabbits immunized with coronavirus Mebus strain, at $37^{\circ} \mathrm{C}$ for 1 hour and at the end of the incubation period virus and serum mixtures were inoculated on to HRT-18 cell cultures. After 1 hour incubation period, all inoculated cell culture wells were washed three times with D-MEM containing pancreatine and added to same medium and incubated for 7 days. CPE formation was observed daily during incubation period.

RNA was extracted from HRT supernatant infected with centrifuged $10 \%$ fecal suspensions and control samples $\left(\mathrm{dH}_{2} \mathrm{O}\right.$ and noninfected HRT cell supernatant as negative control and Mebus strain of $\mathrm{BcoV}$ as positive control) using EZ-RNA total RNA isolation kit according to procedure recommendations by manufacturer (Biological Industries Co., Israel). The RNA pellet was resuspended with $30 \mu \mathrm{l}$ RNase free $\mathrm{H}_{2} \mathrm{O}$.

RT-PCR procedure was performed as previously described. $2 \mu \mathrm{l}$ of downstream primer (50 pmol BCV-2 5'-AGA ATG TCA GCC GGG GTA T-3') was added to a tube containing, $8 \mu 1$ of RNA sample. The tube was incubated at $95^{\circ} \mathrm{C}$ for $2 \mathrm{~min}$ and then cooled on ice for 5 min. RT-PCR mixture containing $10 \mu 1$ sample, $5 \mu 1$ 5x M-MLV Buffer (250 mM Tris-HCl, $\mathrm{pH} 8.3,375 \mathrm{mM}$ potassiumchloride, $15 \mathrm{mM}$ Magnesium chloride, 50mM DTT), $2 \mathrm{mM}$ of each of deoxynucleotides, 20U M-MLV reverse transcriptase (Promega), were used in RT-PCR reaction. Reaction was incubated at $37^{\circ} \mathrm{C}$ for 60 $\min$.

PCR procedure was performed as previously described (Cho and others 2001). PCR mixture containing $5 \mu \mathrm{l}$ the sample cDNA, $5 \mu 1$ 10xPCR Buffer (100 mM Tris-HCl, pH 8.0, 500 $\mathrm{mM}$ potassiumchloride, $0.8 \%$ Nonidet $\mathrm{P} 40$ ), 2 $\mathrm{mM} \mathrm{MgCl} 2,2 \mathrm{mM}$ of each of deoxynucleotides, 1U Taq DNA polymerase (Fermantes), 50 pmol of each primers (BCV-1 5'-GCC GAT CAG TCC GAC CAA TC-3') and (BCV-2 5'-AGA ATG TCA GCC GGG GTA T-3') were used in PCR reaction. The mixture was preheated for 4 min at $94{ }^{\circ} \mathrm{C}$, subjected to 37 cycles of $1 \mathrm{~min}$ at $94{ }^{\circ} \mathrm{C}, 1 \mathrm{~min}$ at $55^{\circ} \mathrm{C}$ and $2 \mathrm{~min}$ at $72{ }^{\circ} \mathrm{C}$. A final extension step was performed $7 \mathrm{~min}$ at 72 ${ }^{\circ} \mathrm{C}$. The amplified PCR products were stained with etidium bromide and visualized under ultraviolet light on $1.5 \%$ agarose gel. (Figure 1) 
The data were expressed as mean $\pm \mathrm{SE}$. The significance between the mean values was determined by Student's t-test. For all comparisons, values of $\mathrm{P}<0.05$ were considered significant.

\section{Results}

Clinical findings observed in cows suffering from WD were characterized by a sudden onset of watery diarrhea and profound decrease in milk production (40\%). Faeces of 10 cows was bloody and was containing mucus. In addition, these cows were severely depressed and moderately dehydrated, mild pale mucosal membranes, tachycardia (range: $92-104$ beats/ minute, reference range: $60-80$ beats/minute), high respiratory rate (range:40- 52 breaths/ minute; reference range: 10 - 30 / breaths/minute), normal body temperature $(37.8-38.9 \mathrm{C}$; reference range: $37.8-39.2 \mathrm{C}$ ), and decreased ruminal motility (range: $3-6 / 5$ minutes; reference range: 8-12/5 minutes) were other clinical findings observed. Faeces of other two cows were dark green, watery and homogenous with little odour. In these cows, body temperatures (range: 38.2-39.1 C), respiratory rates (range: 24-28 breaths/minute) pulse rates (range: $72-80$ beats/ minute) and ruminal motility (range: 8-12/ 5 minutes) were within normal limits. In addition, all animals suffering from WD had serous nasolacriminal discharge and mild cough. Clinical diagnosis of WD was made according to clinical examination.

Table 1. Results of bacterial culture, virological and coccidial isolation in cows with winter dysentery

Tablo 1. Kış dizanterili sığırlarda bakteri kültürü, virolojik ve coccidia izolasyon sonuçları

\begin{tabular}{|cccc|}
\hline $\begin{array}{c}\text { Number of } \\
\text { Cattle }\end{array}$ & $\begin{array}{c}\text { Bacteriologic } \\
\text { culture }\end{array}$ & $\begin{array}{c}\text { Virus isola- } \\
\text { tion }\end{array}$ & $\begin{array}{c}\text { Coccidial } \\
\text { isolation }\end{array}$ \\
\hline 1 & Campylobacter spp & BcoV & negative \\
2 & negative & negative & negative \\
3 & Campylobacter spp & negative & negative \\
4 & negative & negative & negative \\
5 & Campylobacter spp & BcoV & negative \\
6 & negative & negative & negative \\
7 & negative & BcoV & negative \\
8 & negative & negative & negative \\
9 & negative & negative & negative \\
10 & negative & negative & negative \\
11 & negative & negative & negative \\
12 & Campylobacter spp & negative & negative \\
\hline
\end{tabular}

Compared to healthy cattle, haematological results including hematocrit rates, erythrocyte counts, haemoglobin concetrations, serum urea, creatinine and total protein concentrations $(\mathrm{p}<0.05)$ were higher in cattle with winter dysentery. In addition, serum urea, creatinine and total protein concentrations were higher $(\mathrm{p}<0.05)$ in cattle suffering from WD (Table 2). No Eimeria oocysts were detected in faecal samples of examined animals.

Table 2. Mean ( \pm SE) biochemical and haematological findings in cows suffering from Winter Dysentery (WD)

Tablo 2. Kış dizanterili sığırlarda biyokimyasal ve hematolojik bulgular

\begin{tabular}{|c|c|c|}
\hline Parameters & WD cows $(n=12)$ & $\begin{array}{l}\text { Healthy Cows } \\
\quad(n=12)\end{array}$ \\
\hline Leukocyte (x 103/I) & $7.6 \pm 1.2$ & $6.9 \pm 0.9$ \\
\hline Neutrophile ( x 103/l) & $2.9 \pm 0.8$ & $3.3 \pm 0.3$ \\
\hline Lymphocyte ( x 10³/I) & $3.8 \pm 0.3$ & $3.9 \pm 0.2$ \\
\hline Eosinophile ( x 10³/I) & $0.6 \pm 0.2$ & $0.7 \pm 0.4$ \\
\hline Erythrocyte ( x $10^{6}$ /I) & $7.4 \pm 0.7^{a}$ & $5.7 \pm 0.3^{b^{*}}$ \\
\hline Hemoglobin (g/dl) & $14.4 \pm 2.1^{a}$ & $10.7 \pm 1.3^{b^{*}}$ \\
\hline Hemotocrite (\%) & $42.3 \pm 5.6^{a}$ & $33.4 \pm 4.1^{b^{*}}$ \\
\hline Urea ( mg/dl) & $52.4 \pm 2.1^{a}$ & $29.7 \pm 3.4^{b^{*}}$ \\
\hline Creatinine (mg/dl) & $2.1 \pm 0.3^{a}$ & $1.4 \pm 0.2^{b^{*}}$ \\
\hline AST ( IU/L) & $124.5 \pm 13.1$ & $121 \pm 10.2$ \\
\hline CK (IU/L) & $158.3 \pm 12.2$ & $166.2 \pm 7.4$ \\
\hline Total protein ( g/dl) & $7.9 \pm 0.6^{a}$ & $7.1 \pm 0.4^{b^{*}}$ \\
\hline $\mathrm{Ca}(\mathrm{mg} / \mathrm{dl})$ & $9.1 \pm 0.4$ & $9.4 \pm 0.7$ \\
\hline$P(m g / d l)$ & $6.8 \pm 0.3$ & $6.6 \pm 0.2$ \\
\hline $\mathrm{K}(\mathrm{mEq} / \mathrm{L})$ & $5.1 \pm 0.4$ & $4.9 \pm 0.7$ \\
\hline
\end{tabular}

* Differences between the values on the same row are found to be statistically significant $(\mathrm{p}<0.05)$

BcoV was isolated from 3 faecal samples collected from the affected animals and seen CPE focuses at the first passages on HRT cells consisting of syncytial formation and lysis of the infected monolayers and identified by SNT and PCR. The titers of BcoV were found as TCID $_{50} 10^{4.5} / \mathrm{ml}, 10^{4.5} / \mathrm{ml}$ and $10^{5.0} / \mathrm{ml}$ respectively (Figure 1).

A total of 12 faecal samples for bacterial culture were collected from affected cattle and Campylobacter spp. were isolated from 4 of 12 cows suffering from WD (Table-1).

Ten cattle with dehydration were treated with the intravenous administration of 10 to 15 liters of Lactated Ringers solution and 5\% Dextrose (Eczacibası Inc., Istanbul, Turkey) as far as dehydration findings were eliminated. Bread yeast was given orally to all affected cows at a 
dosage of $1 \mathrm{gr} / \mathrm{kg}$ once a day for 5 days. In addition, levamisole (i.m. $2.5 \mathrm{mg} / \mathrm{kg}$, once a day for 3 days, Actipar ${ }^{\circledR}$, Alke Inc., Istanbul, Turkey), tylosine $(10 \mathrm{mg} / \mathrm{kg}$, i.m, qh12 for 5 days; Tylan ${ }^{\circledR}$, Lilly-Elanco Inc., Istanbul, Turkey) were administered to all animals with diarrhea.

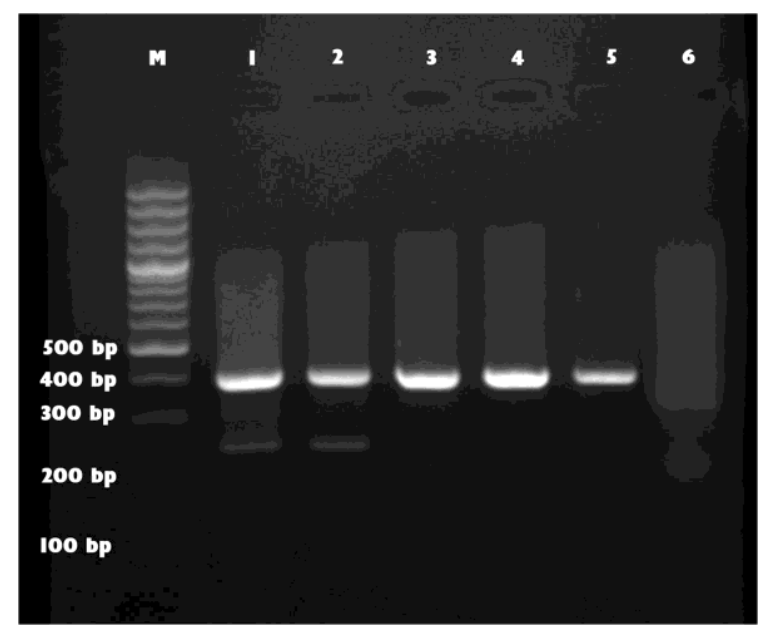

Figure 1. Agorose jel electrophoresis of PCR products of BcoV field strains

Şekil 1. Bco V saha suşunun Agoroz jel
eloktroforezi

M; 100 bp DNA ladder. Line 1; Bovine Coronavirus DNA prepared from infected cell culture fluid of Mebus strain of BcoV Lane 2-5 Bovine Coronavirus DNA prepared from infected cell culture fluid of the sample; Lane 6; DNA from non-infected HRT cell supernatant

\section{Discussion}

Winter Dysentery is a disease affecting mostly household, adult milking cows in postpartum period at winter times. However, cases in the present study were identified in April. Although low mortality rates, disease causes serious economical impact over dairy herds because of loss of body condition and milk yield $^{1}$. Likewise, in the cases presented, substantial decrease of milk yield was observed throughout disease and for up to 6 weeks following recovery.

Winter dysentery is characterized by an acute onset of watery, sometimes blood containing diarrhea and $25-95 \%$ production loss. Diarrhea could be accompanied or preceded by nasolacrimal discharge and/or cough. Other possible signs include mild colic, dehydration, depression, a brief period of anorexia and decrease in body condition at certain level ${ }^{14,1}$. Similarly, presented cases show acute onset of watery diarrhea, and a marked decrease in milk production. Furthermore, ten cows had severe watery diarrhea containing blood and mucus and also cows were dehydrated and depressed. Respiratory findings including mild cough and serous nasolacrimal discharge were observed in all cows suffering from WD. It is notified that Bovine coronavirus, which is accepted as the primary etiologic agent of Winter Dysentery, can cause infection of respiratory epithelium in cattle ${ }^{15,13,16,17}$. Therefore, both enteric and respiratory findings could be observed in WD as detected in the cases presented.

Disease was believed to be caused by Campylobacter fetus var. jejuni but incompatibility to isolate bacterium from all cases similar to winter dysentery and inability of bacterium to cause clinical signs similar to WD in experimental infections suggests that bacterium could be secondary pathogen in the course of disease $^{14,1}$. In study presented, a total of 12 faeces samples were collected from the affected cattle for bacterial culture. However Campylobacter spp. was isolated only from 4 of the cows with WD. In addition, a local BcoV strain was isolated from 3 faecal samples collected from same animals. Saif et al. (2008) reported that feces of the $90 \%$ of the animals from an outbreak of winter dysentry were $\mathrm{BCoV}$ positive ${ }^{23}$. Results of faeces of other animals for bacterial examination were negative. These results indicate that $\mathrm{BcoV}$ is probably the primary pathogen of WD however Campylobacter spp. may only contribute to pathogenesis of the disease as a secondary pathogen.

Unlike neonatal diarrheic calves ${ }^{18-21}$, there are few reports, associated with intestinal coranavirus infection in adult $\operatorname{cows}^{5,6,22-24}$. A bovine coronavirus $(\mathrm{BCoV})$ closely related to the virus that causes diarrhea in neonatal calves, has been implicated as the etiologic agent of $\mathrm{WD}^{4,11,19,15,20}$. Evidence for Coronavirus as an etiologic agent of WD is the ability of virus to induce disease similar to winter dysentery, affected cattle seroconvert to BCV and virus and thus virus particles could be isolated from faces of affected cattle ${ }^{25,13}$.

Other causes of acute diarrhea, such as BVD, salmonellosis, coccidiosis, always should be considered in clinical diagnosis ${ }^{14,26,1,27}$. Although there are major differences between clinical course of WD and diseases mentioned above all cows were evaluated for BVD, salmonellosis and coccidiosis, eventually results of 
examinations of 12 faeces samples for BVD, salmonella spp and eimeria spp. were negative.

None of the results of haematology are pathognomic for winter dysentery. In the present study, serum urea and creatinine concentrations, indicators of glomerular filtration, were mildly high in cattle with dysentery, probably due to dehydration. Similarly, high hematocrit rates, total protein levels, erythrocyte counts and haemoglobin concentrations may be a result of dehydration.

WD has a high morbidity but low mortality rates and features of faeces return to normal in 2-3 days in most animals affected by WD. Treatment for WD is based on providing basic medical support to affected animals ${ }^{14,28,1}$. Clinical improvement was observed in all the animals treated with bread yeast, levamisole, tylosin, lactated Ringers solution and 5\% dextrose solution at third day and full recovery of all animals was observed at the end of fifth day of treatment.

Results of this study represent the first local coronavirus from a cattle herd with winter dysentery in Turkey. Winter Dysentery needs to be considered in the differential diagnosis of cattle with clinical signs such as severe watery diarrhea with blood and mucus, dehydration, depression nasolacrimal discharge or cough fever. As etiologic agents in these cases should be taken into consideration, and in preventive measures against winter dysentery, Coronavirus along with Campylobacter spp should be taken into consideration. On the other hand eight negative results of cattle with symptoms of WD indicates that ethiology of the disease is stil not clearly elucidated and different pathogens other than $\mathrm{BCoV}$ and Campylobacter could also be involved in pathogenesis of the disease

\section{References}

1. Radostits, O.M., Gay, C.C., Blood, D.C., Hinchcliff, K.W., 2004. Winter dysentery in cattle In:Textbook of the diseases of cattle, sheep, pigs, goats and horses . Veterinary Medicine, O Rasostits, CGay, DC Blood, et al., (Ed). WB Saunders, London, 1126-1128.

2. Potecea, E., Pârvu, M., Turcu, D., Bădic,E.L., Bibicu,C., Trăncuńă, A., 2008. An epizootologic study concerning the winter dysentery in dairy cow. Bull Usamv Vet Med, 65, 345-348.

3. Benfield, D.A., Saif, L.J., 1990. Cell culture propagation of a coronavirus isolated from cows with winter dysentery. J Clin Microbiol, 26, 1454-1457.
4. Benfield, D.A., Saif, L.J. 1990. Cell culture propagation of a coronavirus isolated from cows diarrhea in great britain and Denmark. Vet Microbiol, 3, 101-113.

5. Brandão, P.E., Gregori, F., Sforsin, A.J., Villarreal,L.Y.B., Jerez, J.A., 2007. Winter dysentery in cows associated with bovine coronavirus (BcoV). Arq Bras Med Vet Zoo, 59, 1074-1076.

6. Durham, P.J.K., Hassard, L.E., Armstrong, K.R., Naylor, J.M., 1989. Coronavirus-associated diarrhea (winter dysentery) in adult cattle. Can Vet J, 30, 825-82.

7. Van Kruiningen, H.J., Castellano, V.P., Torres, A., Sharpee, R.L., 1991. Serologic evidence of coronavirus infection in new york and new england dairy cattle with winter dysentery. J Vet Diagn Invest, 3, 293-296.

8. Van Kruiningen, H.J., Castellano, V.P., Koopmans, M., LL Harris,L.L., 1992. A serologic investigation for coronavirus and breda virus antibody in winter dysentery of dairy cattle in the northeastern united states. J Vet Diagn Invest, 4, 450-452.

9. Hendrix, C.M., 1998. Diagnostic Veterinary Parasitology. St Louis, Mosby Inc.

10. Quinn, P.J., Carter, M.E., Markey, B.K., Carter, G.R., 2000. Campylobacter species In: Clinical Veterinary Microbiology. Quinn PJ, Carter ME, Markey BK, et al. (Ed),. Mosby, St Louis, MO. 209-236.

11. Bridger, J.C., Woode, G.N., Meyling, A., 1978. Isolation of coronaviruses from neonatal calf diarrhea in Great Britain and Denmark. Vet Microbiol, 3, 101-113.

12. Hasoksuz M., Lathrop, S.L., Gadfield, K.L., Saif, L.J., 1999. Isolation of bovine respiratory coronaviruses from feedlot cattle and comparison of their biological and antigenic properties with bovine enteric coronaviruses. Am J Vet Res, 60, 1227-1233.

13. Hasoksuz, M., Hoet, A.E., Loerch, S.C., Wittum,T.E., Nielsen, P.R., Saif, L.J., 2002. Detection of respiratory and enteric shedding of bovine coronaviruses in cattle in an ohio feedlot. $\mathbf{J}$ Vet Diagn Invest, 14, 308-313.

14. Charles, G., 2002. Winter dysentery in cattle. Smith BP (Ed), Large Animal Internal Medicine. Mosby, St. Louis, MO., 773-775.

15. Cho, K.O., Hasoksuz, M., Nielsen, P.R., Chang, K.O., Lathrop, S., Saif, L.J., 2001. Crossprotection studies between respiratory and calf diarrhea and winter dysentery coronavirus strains in calves and RT-PCR and nested PCR for their detection. Arch Virol, 146, 2401-2419.

16. Hasoksuz, M., Kayar, A., Dodurka, T., Ilgaz A., 2005. Detection of respiratory and enteric shedding of bovine coronaviruses in cattle in northwestern Turkey. Acta Vet Hung, 53, 137-146. 
17. Heckert, R.A., Saif, L.J., Hoblet, K.H., Agres, A.G., 1990. A longitudinal study of bovine coronovirus enteric and respiratory infection in dairy calves in two herds in Ohio. Vet Microbiol. 22, 187- 201.

18. Abraham, G., Roeder, P.L., Zewdu, R., 1992. Agents associated with neonatal diarrhoea in Ethiopian dairy calves. Trop Anim Health Prod, 24, 74-80.

19. Chengping, L., Huochun, Y., Eichorn, W.1991. Coronavirus as an agent of neonatal calf diarrhea in a Chinese dairy cattle farm. J Vet Med B, 38, 473-476.

20. Clark, M.A., 1993. Bovine coronavirus. Brit Vet J, 149, 51-70.

21. Yao, L.C.H. and Eichorn, W., 1991. Coronavirus as an agent of neonatal calf diarrhea in a Chinese dairy cattle farm. J Vet Med B, 38, 473-476.

22. Espinasse, J., Visso, M., Laval, A., Savey, M. and Le Layec,C., 1982. Winter dysentery : a coronavirus - like agent in the feces of beef and dairy cattle with diarrhoea. Vet Rec, 110, 385.
23. Saif, L.J., Redman, D.R., Brock, K.V., Kohler, E.M. and Heckert,R.A.,1988. Winter dysentery in adult dairy cattle: detection of coronavirus in the feces. Vet Rec, 123, 300-301.

24. Van Kruiningen, H.J., Khairallah, L.H., Sasseville, V.G., Wyand, M.S.and Post, J.E.,1987. Calfhood coronavirus enterocolitis: a clue to the etiology of winter dysentery. Vet Pathol, 24, 564567.

25. Crouch, C.F., Acres, S.D., 1984. Prevalence of rotavirus and coronavirus antigens in the feces of normal cows. Can J Comp Med, 48, 340-342.

26. Kahrs, R.F., Scott,F.W., Hillman, R.B.,1973. Epidemiologic observations on bovine winter dysentery. Bovine Practice, 8,36-39.

27. Scott, F.W., Kahrs, R.F., Campbell, S.G., Hillman, R.B.,1973. Etiologic studies on bovine winter dysentery. Bovine Practice, 4, 40-43.

28. Pusterla, N., Braun, U.,1996. Prophylaxis of intravenous catheter-related thrombophlebitis in cattle. Vet Rec, 139, 287-289. 
